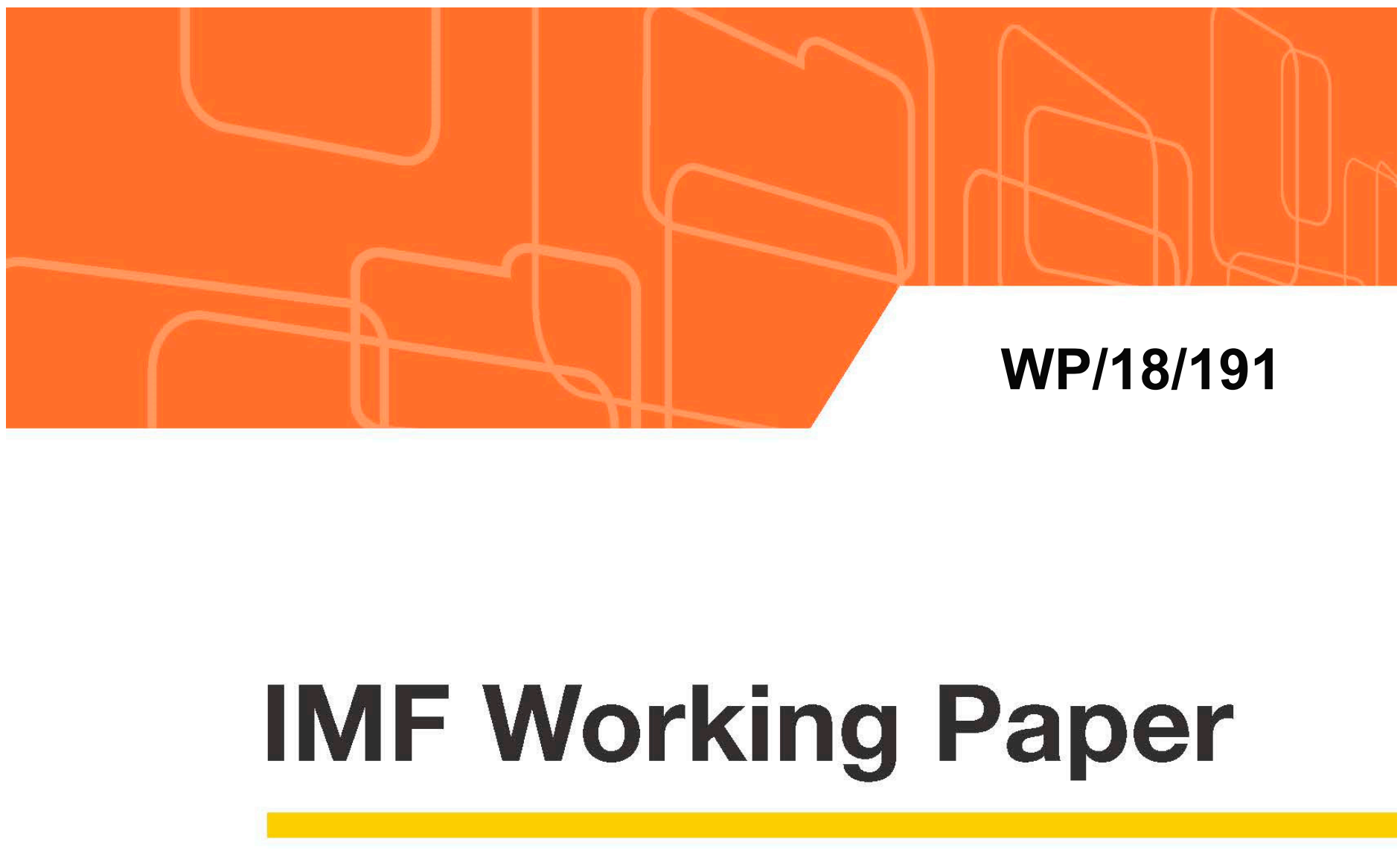

\title{
Monetary Policy with Negative Interest Rates: Decoupling Cash from Electronic Money
}

by Katrin Assenmacher and Signe Krogstrup

IMF Working Papers describe research in progress by the author(s) and are published to elicit comments and to encourage debate. The views expressed in IMF Working Papers are those of the author(s) and do not necessarily represent the views of the IMF, its Executive Board, or IMF management. 


\title{
IMF Working Paper
}

Research Department

\section{Monetary Policy with Negative Interest Rates: Decoupling Cash from Electronic Money ${ }^{1}$}

\section{Prepared by Katrin Assenmacher and Signe Krogstrup}

Authorized for distribution by Signe Krogstrup

August 2018

\section{IMF Working Papers describe research in progress by the author(s) and are published to elicit comments and to encourage debate. The views expressed in IMF Working Papers are those of the author(s) and do not necessarily represent the views of the IMF, its Executive Board, or IMF management.}

\begin{abstract}
Monetary policy space remains constrained by the lower bound in many countries, limiting the policy options available to address future deflationary shocks. The existence of cash prevents central banks from cutting interest rates much below zero. In this paper, we consider the practical feasibility of recent proposals for decoupling cash from electronic money to achieve a negative yield on cash which would remove the lower bound constraint on monetary policy. We discuss how central banks could design and operate such a system, and raise some unanswered questions.

JEL Classification Numbers: E42; E52, E58

Keywords: Zero lower bound; Monetary policy framework, Dual local currency regime, Legal tender

Author’s E-Mail Address: katrin.Assenmacher@ecb.europa.eu, skrogstrup@imf.org

1 The views expressed in this paper are those of the authors and do not necessarily represent those of the European Central Bank or the International Monetary Fund, its Management or its Board. We thank Larry Christiano, Giovanni Dell'Ariccia, Daniel Heller, Umang Rawat, Will Roberds and Ted Truman as well as seminar participants at the Federal Reserve Bank of Atlanta, the University of Lausanne, the ROME Workshop Frankfurt and the Swiss National Bank for comments. Wenjie Li provided excellent research assistance.
\end{abstract}




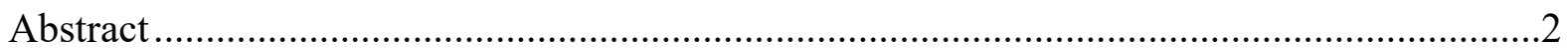

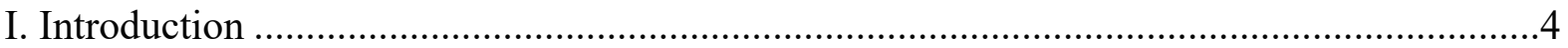

II. Why not Simply Phase Out Cash .............................................................................

II. Decoupling Cash From Electronic Money ..............................................................

A. How Would it Work? Setup and Operating Framework ...........................................

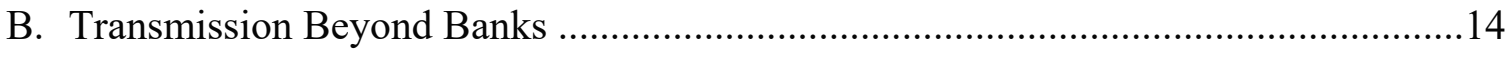

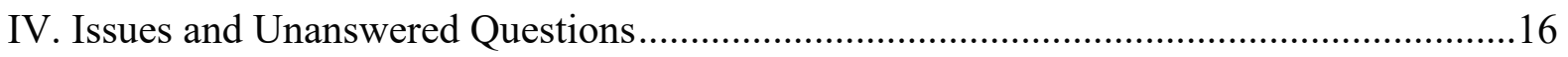

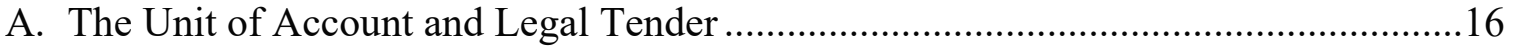

B. Behavioral Responses in the Transition............................................................... 19

C. Deeply Negative Rates and Monetary Policy Transmission....................................20

D. Deeply Negative Rates and financial Stability .....................................................22

E. Implications for Seigniorage Revenues ..........................................................24

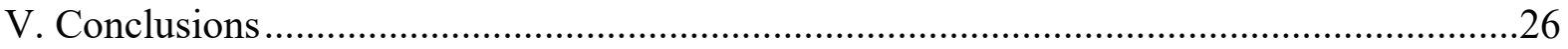

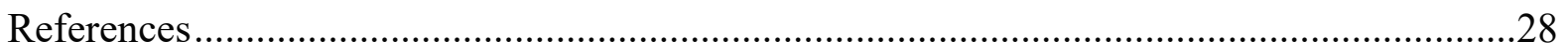




\section{INTRODUCTION}

The global financial crisis brought policy rates to the so-called zero lower bound (ZLB) in many countries. Some countries are still at this lower bound ten years after, and others are very close, as illustrated in Figure 1 for OECD countries. Larry Summers recently warned that central banks would not have sufficient policy space to counter the next recession, as the normal playbook would suggest countries should be able to cut rates by 500 basis points to effectively respond to important negative shocks. ${ }^{2}$ Figure 1 shows that all but two OECD countries have monetary policy space that exceeds 500 basis points, and only three have policy space in excess of 250 basis points.

Figure 1. Monetary Policy Space and the ZLB constraint in 2017

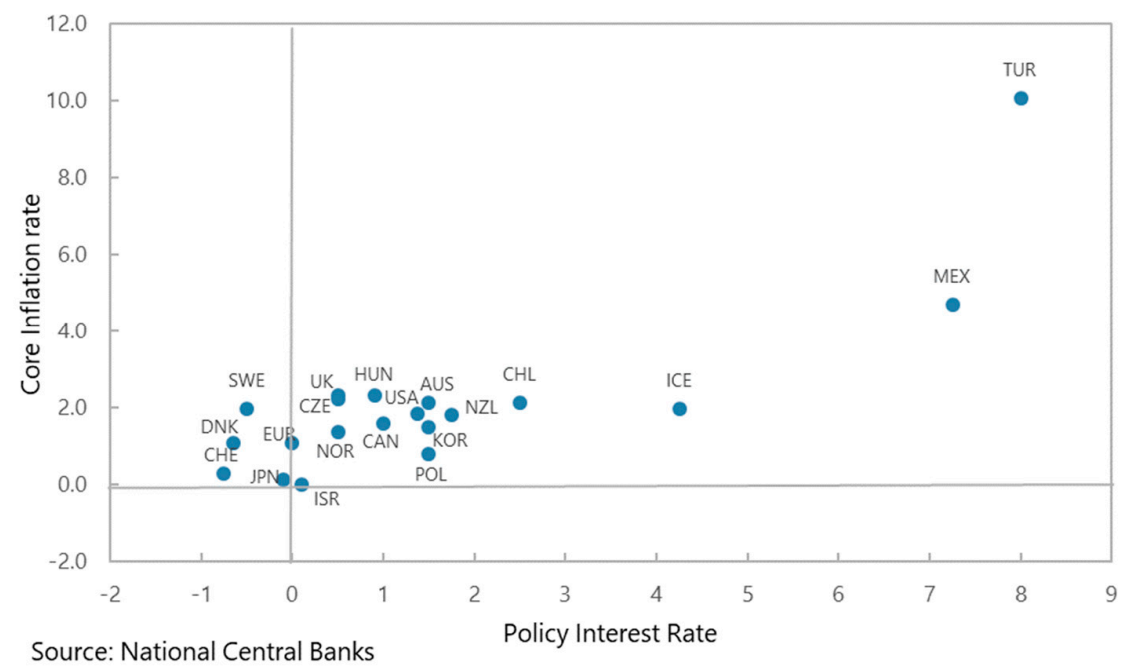

The lower bound on interest rates is due to the existence of cash, which by design yields a nominal interest rate of zero. ${ }^{3}$ If a central bank attempts to move its policy rate significantly below zero, commercial banks will see their interest margin compressed as long as they do not charge negative interest on deposits. ${ }^{4}$ If they pass on negative interest to depositors, those may in turn decide to switch from (negative)

2 See "Summers Warns the Biggest Economies Are Not Prepared for Another Recession", 18 June 2018, https:/www.bloomberg.com/news/articles/2018-06-18/summers-warns-biggest-economies-not-prepared-fornext-downturn.

3 In this article, the term cash refers to physical currency, i.e. coins and banknotes.

4 This compression is more pronounced if a bank relies more on deposit funding relative to funding from money and capital markets. 
interest-bearing deposits to cash, which could lead to a substantial outflow of deposits from the banking sector. ${ }^{5}$

This risk of substitution from deposits and reserves into cash is at the core of the existence of a lower bound on interest rates. The experience of recent years suggests that the lower bound is somewhat below zero, as storing and handling cash is associated with cost and inconvenience compared to using money in a deposit account. No large-scale substitution toward cash has been observed in connection with negative interest rates as of yet. But there is no doubt that substitution would eventually occur if interest rates were to become sufficiently negative. Substitution into cash on a large scale would erode banks' funding base. The intended stimulating effects of interest-rate cuts substantially below zero would be undermined, as the zero rate on cash, and not the negative rate on central bank reserves, would become the economically relevant interest rate.

The lower bound on interest rates hence poses a hard constraint on the ability of monetary policy to counter cyclical downturns, deflation and unemployment in an environment where interest rates are already low. Numerous proposals have been made to increase the ability of monetary policy to provide stimulus when faced with the lower bound on short-term interest rates, such as raising the inflation target, adjusting exchange rate policy, conducting large scale asset purchases or phasing out cash to allow for substantially negative interest rates (Blanchard 2010, Williams 2017, Svensson 2003, Ball et al. 2016 and Rogoff 2014). Each proposal has advantages and drawbacks, and only the latter fully removes the lower bound constraint.

In this paper, we discuss the practical feasibility of decoupling cash from electronic money, as a way of fully removing the lower bound on monetary policy while preserving a role for cash (Kimball 2015, Buiter 2007, Goodfriend 2016). Decoupling cash from electronic money, in effect establishing a dual local currency system, would allow for implementing substantially negative interest rates without a large-scale substitution into cash, by engineering a similarly negative yield on cash in terms of electronic currency. We discuss how such a system could be designed and operated. We also highlight some remaining unanswered questions concerning the system's legal and institutional implications, the transmission of monetary policy, financial stability and seigniorage revenues, and point to areas where more research is needed. While decoupling the value of cash from electronic money might sound impracticable, we conclude that with some further conceptual development and research, the system is feasible and would fully restore monetary policy space with negative interest rates. Its pros and cons will differ across countries, and should be considered alongside the pros and cons of other proposals for increasing monetary policy space in a low-interest rate environment.

5 Banks themselves face a similar trade-off. When the negative interest rate on reserves exceeds the storage cost for vault cash they may decide to convert excess reserves into cash. Storing large amounts of cash centrally, however, will create security and insurance issues. Moreover, in many countries vault cash is part of the minimum-reserve regulation, giving the central bank a lever to influence cash holdings at banks (see e.g. Switzerland). Affecting the behavior of private agents is much more difficult. 
The paper is structured as follows. The next section sets the stage by first considering why abolishing cash may not be practically feasible or desirable in many countries. In Section III, we describe how the dual local currency system that preserves a role for cash but allows for negative interest rates would work in practice, from the central bank's operating framework to the transmission of negative interest rates to cash, deposits and payments in the broader economy. Section IV addresses some open questions and the final section concludes.

\section{Why Not Simply Phase Out Cash?}

Rather than decoupling cash from electronic money, it would arguably be much simpler to phase out cash altogether, which would achieve many of the same advantages in terms of allowing monetary policy to operate below the lower bound. However, while some countries, notably Sweden, are quickly heading in the direction of a cashless society, other countries remain strongly reliant on cash, as shown in Figure 2. Figure 3 shows that only two countries - Sweden and Norway - saw an outright reduction in currency in circulation in percent of GDP in the past decade. Countries with relatively high outstanding amounts of currency in circulation also had high growth rates in the past decade, pointing to how developments in outstanding cash differs and to some extent diverges across countries.

Moreover, there are reasons why phasing out cash completely may be premature or undesirable in some countries.

Figure 2. Currency in circulation in percent of GDP in 2017

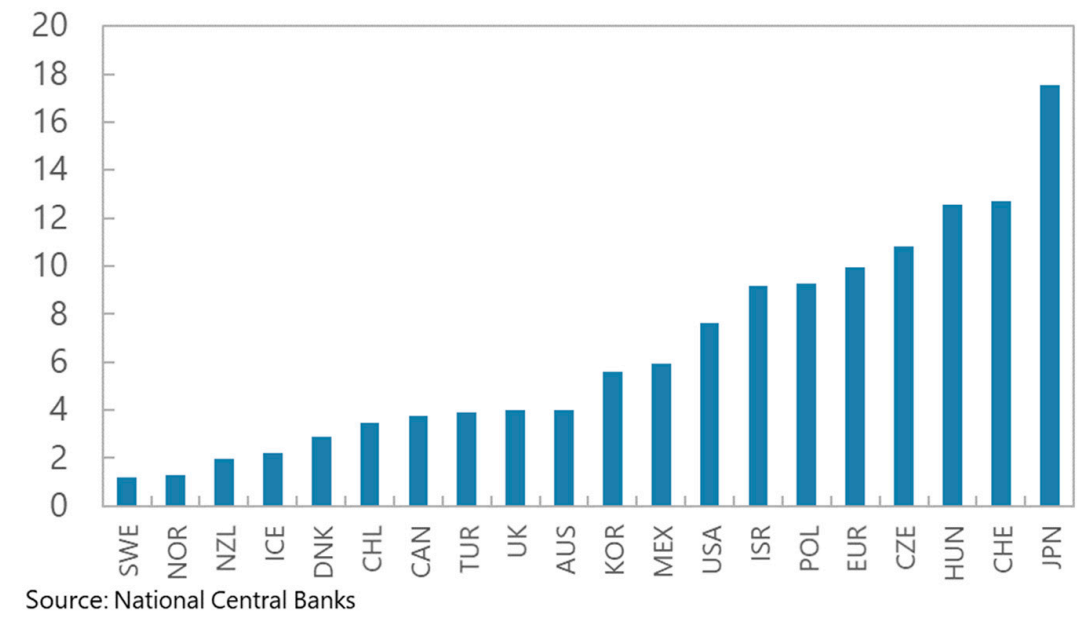


Figure 3. Currency in circulation in percent of GDP change since 2007 and level in 2007

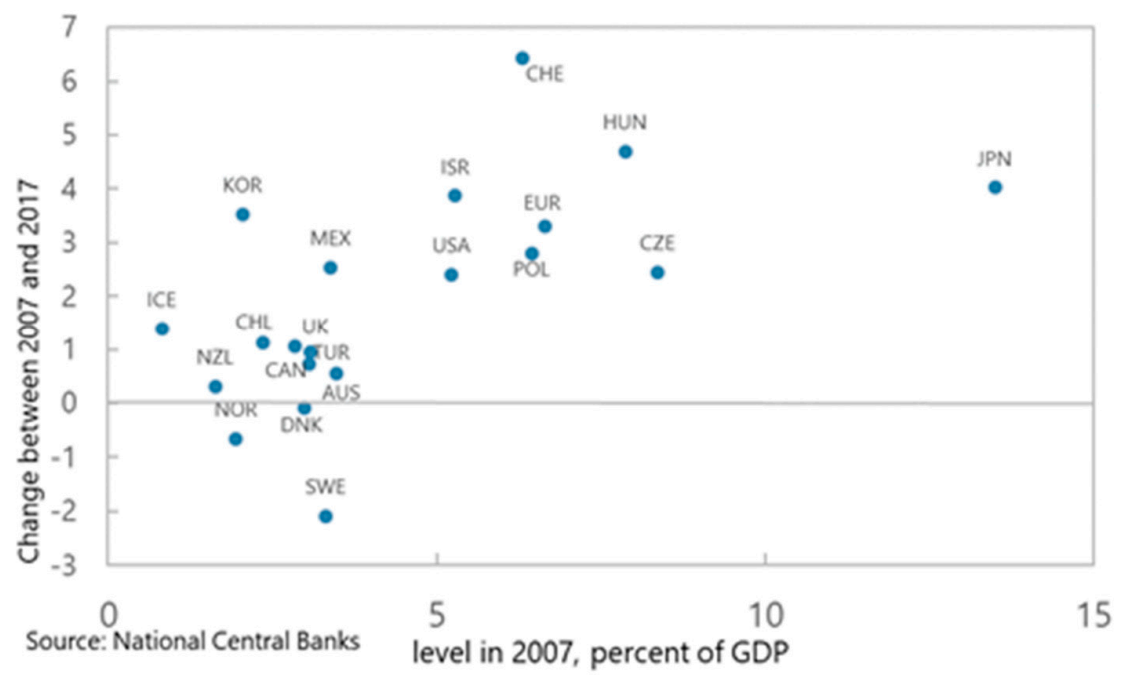

Cash currently serves three key uses in our societies. It plays a key role in retail payments, it is used for storage, i.e. hoarding of banknotes as a means of saving, and it is used for tax evasion and illegal activities. Rogoff (2014) argues that the first two functions of cash can nowadays be conveniently performed by electronic forms of money, whereas the prevalent use of cash in tax evasion and illegal activities is an important reason for central banks to consider phasing it out. An added benefit to phasing out cash, he argues, is that a society without physical currency has no lower bound on nominal interest rates, and monetary policy can address cyclical downturns without constraints.

Cash remains important in retail payments in many countries, however. For this reason alone, central banks with mandates to promote the stability of payments systems will be reluctant to phase out cash actively. In the euro area, for example, cash is still the dominant payment instrument at the point of sale (Esselink and Hernández 2017), though the use of cash varies strongly between European countries. ${ }^{6}$ Removing cash as a payments option before electronic means of payment have become near-universal could disrupt the retail economy. Moreover, the use of cash and access to electronic means of payment is not evenly distributed across demographic groups. Low-income and older population groups, for example, tend to use electronic means of payments less, and are not about to increase their use. Phasing

6 Similar results are found for Switzerland, see Swiss National Bank (2017) 
out cash could be particularly disruptive for the financial livelihoods of such population segments. ${ }^{7}$

Beyond the stability of payments systems, there are institutional and cultural reasons why some countries may not be able to do away with cash, at least in the near term. That cash payments are anonymous is seen in some countries as important for ensuring the right to privacy. Another key property exclusive to cash is exactly that it is not electronic. If electronic systems break down, cash is still usable and hence provides a hedge of the retail financial system against electronic disruptions. This has turned out to be of high value in areas plagued by natural disasters that interfere with electronic networks. Preparations for natural disasters in fact often include securing the provision of sufficient cash stocks. ${ }^{8}$ Finally, if cash is abolished, the decision would be difficult to reverse, whereas in a dual local currency system all payment instruments that are in use today in principle could be continued to be used, meaning that the corresponding infrastructures would remain in place and running.

\section{Decoupling CASH FRom Electronic Money}

An alternative to phasing out cash is to make holding cash as costly as electronic money when interest rates are negative. Various proposals have been put forth for how to impose a cost on cash holdings. Gesell (1916) suggested discouraging cash hoarding by introducing a demurrage fee. His idea was that money would need to be stamped at regular intervals to remain valid and that these stamps would have to be purchased. Such a scheme was implemented in some Austrian and German communities during the Great Depression, but the practice was soon stopped by the respective central banks. A similar but untried proposal is to let banknotes expire at certain dates, forcing their holder to pay a conversion fee for changing them into new, valid banknotes (Seltmann 2010). Goodfriend (2000) suggested integrating magnetic strips into banknotes that record when the note was last withdrawn from the banking system and how much carry tax on that note is due. This option gets very close to simply replacing cash with electronic money. Mankiw (2009) proposed a lottery scheme that declares a certain number of banknotes invalid at regular intervals. While all these ideas achieve a carry cost on cash, all of them seem unworkable from a practical perspective.

A different proposal to implementing a negative carry cost on cash is to change the one-to-one conversion of reserves held at the central bank into cash. Buiter (2007) shows that, in theory, a negative yield on cash can be achieved by decoupling the

7 One option is to tailor public policy to achieving universal access to electronic means of payment, and some countries, in particular Sweden, are currently heading down this route (see, e.g. Skingsley 2016). But such changes to the structure of payments systems take time and cannot be achieved overnight.

See e.g. http://ready.gov. Cheney (2006, p. 7) documents that in advance of the hurricane Katrina the Federal Reserve Bank had to dispense exceptionally high amounts of cash to the affected regions. In light of the need to distribute financial relief to affected families, however, schemes to improve the electronic payment infrastructure were seen as highly important as well. 
value of cash from the value of electronic money and allowing cash to depreciate over time in terms of electronic money. Agarwal and Kimball (2015) develop the practical aspects of how such a system would work in more detail. Effectively, a decoupling would entail a split of the domestic money supply into two different local currencies: cash and central-bank reserves. Such a dual local currency system would allow the central bank to continue conventional monetary policy below the current effective lower bound. It would preserve the role of cash as a means of payment and, as we argue below, could be implemented with relatively small changes to central-bank operating frameworks. It should be workable from a practical perspective.

A system with separate cash and electronic currency circulating in parallel gives rise to legal and structural questions, however, that would require answers for implementation to be possible. We address these issues in detail below. We follow Agarwal and Kimball's (2015) ideas closely, but go beyond them in several aspects relating to what central banks would need to consider if they were to adopt such a system in practice.

\section{A. How Would It Work? Setup and Operating Framework}

The central bank would divide the monetary base into two separate domestic currencies, which we refer to as cash and reserves in the following. Cash would be issued in physical banknotes and coins. Reserves would be issued only electronically. Reserves would pay nominal interest, possibly negative. ${ }^{9}$ The overnight rate on reserves is given by $i_{t}{ }_{t}$. We also refer to this rate as the policy rate. Moreover, the central bank would set the spot cash reserve conversion rate for cash withdrawn from or deposited in the central bank's reserve accounts (henceforth referred to as the $C R C$ rate), and supply cash fully elastically on demand against reserves at this price. This cash conversion rate would apply to the central bank's operations with financial institutions that hold reserve accounts with the central bank, i.e. mainly bank counterparties.

Under such a monetary framework, banks depositing cash into their reserve accounts with the central banks would see their reserves credited not at par, but at the prevailing $C R C$ rate. The $C R C$ would apply symmetrically, just like any other exchange rate. Banks taking out cash from their reserve account would see their reserve account debited at the $C R C$ rate. The rate of change of the $C R C$, not its level, would determine the yield on cash in terms of reserves. To remove any incentive for banks to move into cash when a negative interest rate is applied to reserves, the central bank would use the $C R C$ rate to steer the demand for cash, by setting the spot conversion rate between reserves and cash in order to impose a sufficiently deterring negative yield on cash in terms of reserves.

9 Interest on reserves are currently used by several central banks to establish a floor for money market rates and have been discussed as a monetary policy tool in times of high liquidity especially in the US, see Gagnon and Sack (2014). 
Assuming that the negative yield on cash would be set equal to the negative interest rate on reserves to achieve this, the central bank would establish a conversion rate defined by $i_{t}^{C}=\left\{360 \times\left(C R C_{t+d}-C R C_{t}\right)\right\} /\left\{d \times C R C_{t}\right\}$, where the subscript $d$ refers to time units (days) between adjustments of the $C R C$ rate, and $i_{t}{ }_{t}$ is the annualized yield on cash in terms of reserves during that time. ${ }^{10}$ The yield does not need to be equal to the interest rate on reserves. In principle, a slightly less negative yield on cash than the interest on reserves could be enough to deter a shift into cash, given the storage cost of cash and the liquidity services that cash provides. In contrast, if the central bank was aiming to reduce the hoarding demand for cash even further, the yield could be made even more negative. ${ }^{11}$ In essence, the cash reserve conversion rate would give the central bank a tool for controlling the demand for cash relative to the demand for reserves. For ease of exposition, we assume in the following that the conversion rate is set such that the negative yield on cash equals the interest on reserves.

To ensure a smooth functioning of the scheme, the conversion rate applied to the central bank's cash operations with its counterparties would have to be adjusted continuously, preferably daily. The central bank's counterparties are accustomed to sophisticated liquidity provision procedures and would quickly understand the operation of such a system (we discuss transmission beyond the central bank's counterparties in the next section). Discrete jumps in the $C R C$ would redistribute wealth between cash holders and reserve holders at the moment of the jump, which would be destabilizing. Moreover, the chosen adjustment frequency would have to be announced up front to ensure transparency and avoid speculation in the timing of adjustments. For example, at the end of each business day, the central bank could announce that tomorrow's rate of conversion of cash into reserves is $C R C_{t+1}=$ $C R C_{t}\left(1+i_{t+1, t}^{c} / 360\right)$. Alternatively, the central bank could announce a path for the $C R C$ that would be followed until the next policy meeting. If the central bank changes its policy rate, the corresponding new level for tomorrow (or the new path) of the $C R C$ would be announced simultaneously and accordingly. The central bank could use the same setup and frequency for changes in the $C R C$ as for changes to its usual policy rate.

In principle, such a dual local currency system could remain in place when interest rates return to positive territory. Once the fixed costs of introducing such a system are borne, there would be obvious benefits from leaving it in place, to always be ready for an accommodative monetary policy at low interest rates. There could also be disadvantages. Notably, if the system were to result in a structural shift toward noncash payments, it could reduce seigniorage revenues, as we discuss in Section E below.

10 Note that there are no expectations signs in this interest parity because the conversion rate tomorrow and the rate on reserves held from today until tomorrow are both known and set by the central bank.

11 Note that in normal times without a dual local currency such a situation would correspond to an interest-onreserves system with cash paying a zero nominal rate and reserves paying a positive interest rate. 


\section{A numerical example}

Suppose a central bank moves from a zero to a negative rate of $-3 \%$ p.a. on reserve accounts at the central bank. If cash remained convertible one-for-one with central bank reserves, there would be a strong incentive for banks and, in turn, for the non-bank public, to hoard cash. This could trigger a run toward cash, which could endanger economic and financial stability - the lower bound on interest rates would be reached. To prevent a run on cash, the central bank simultaneously announces a shift to a dual local currency system with an initial $C R C_{0}=100$ (defined in units of cash per 100 units of reserves). At the same time, it announces that the yield on cash in terms of reserves is set equal to the interest on reserves (for simplicity of the example), and hence, that tomorrow's $C R C$ will be $C R C_{1}=$ $\frac{100}{(\sqrt[360]{1-0.03})}=100.0085 .{ }^{1}$ After a year with $-3 \%$ p.a. interest on reserves, the CRC rate would be 103 , and 100 units of cash would be converted into roughly 97 units of reserves. Figure 4 depicts this case, based on monthly $C R C$ adjustments for the sake of illustration. As long as the interest rate is negative, banks would receive increasingly more cash over time when they withdraw funds from their account at the central bank. The effective depreciation of cash over the holding period would correspond exactly to the accumulated negative interest on reserves over the same period.

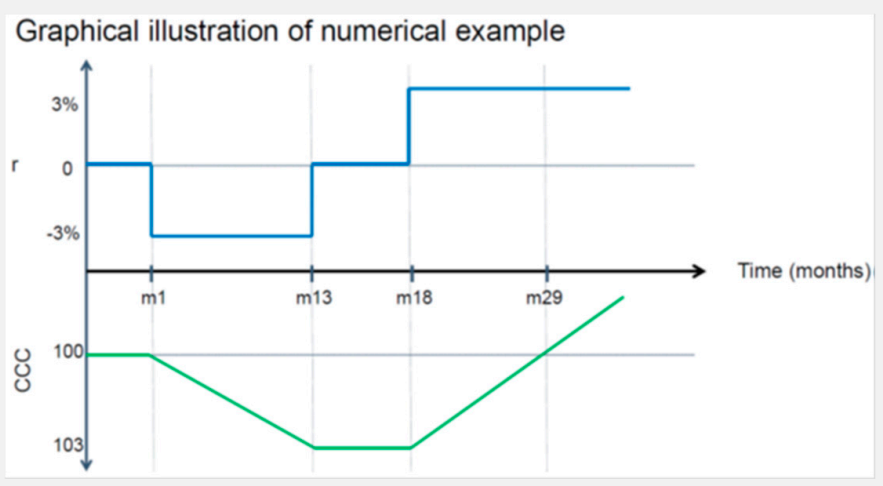

Figure 4. Negative interest rates and the cash-reserve conversion rate

In the example in Figure 4, the negative interest rate is abandoned at month 13. If an exit from the dual local currency system is desired, the conversion rate would have to remain in place for at least the amount of time that it would take to bring the conversion rate back to par. After a period with a negative interest rate, this would imply that the cash yield would have to be positive for a while. In the example in Figure 4, the $C R C$ is kept at 103 for as long as the interest on reserves remains zero. In month 18 , we assume that the central bank wishes to tighten policy by increasing the interest rate to $3 \%$ p.a. Now the $C R C$ rate starts reversing, in order to ensure that the yield on cash in terms of reserves is also a positive $3 \% \mathrm{p}$.a. If the interest rate remains at $3 \%$, the $C R C$ rate returns to par in month 30 . At this point, the system can be safely exited.

1 Using compound interest, the square root expression refers to the daily equivalent gross compound interest of a yearly interest rate of $-3 \%$, with a year defined as 360 days. 
If leaving the system in place is not desired, the central bank cannot exit by simply setting the conversion rate to par once interest rates move back to zero. Such a discrete "appreciation" of cash in terms of reserves would redistribute wealth and be destabilizing. If the central bank was expected to eventually exit in this way, there would be strong speculation in taking out cash before the exit, which would be counterproductive to the purpose and functioning of the system. It would also pose financial stability risks. Instead, an exit can take place without disruption at the time interest rates have been positive for long enough to bring the $C R C$ rate back to par. To increase transparency and avoid disruptive speculation, the central bank could announce up front if and how it plans to exit the system, whether the conversion rate would remain in place or whether it would be abandoned at the moment it is back to par. To illustrate this point and to fix ideas, a numerical example of how a dual local currency system would be operated is presented in the box.

With cash and electronic money unbundled into two distinct local currencies, there would also be two foreign currency exchange rates, namely one for domestic cash per foreign currency, and one for domestic electronic money (central bank reserves) per foreign currency. The relationship between the two foreign exchange rates would in market equilibrium be determined by the central bank's choice of the $C R C$ rate between domestic cash and reserves, as the central bank is the monopoly supplier of both, cash and reserves. The relationship between the three exchange rates would be identical to the relationship between the bilateral exchange rates of three foreign currency pairs, except that in this case, one of the bilateral exchange rates (the $C R C$ rate) would be deterministically fixed by the central bank, whereas the two other rates would be market determined. In this way, there would be no monetary incentive to shift to foreign cash instead of domestic cash under a negative yield on cash.

Figure 5 illustrates the uncovered interest parity (UIP) relations between the foreign currency and the dual domestic currency. If cash depreciates at a rate consistent with the negative interest rate, UIP between the three bilateral exchange rates is assured at all times. Speculators would be indifferent with regard to which currency (electronic, paper or foreign) to invest in. If the central bank were to let cash depreciate more or less quickly than the negative rate on reserves, the two foreign exchange rates for cash and electronic currency would reflect this difference. ${ }^{12}$ Overall, this would not open up any new arbitrage opportunities as compared to the closed-economy case. The only source of potential arbitrage would be the difference in yields between the domestic paper and electronic currency. Adding a third currency to the dual local currency system with the corresponding market-based exchange rates does not change anything with respect to the relation between the two domestic currencies.

It is important to note that the dual local currency system we discuss here is not akin to dual exchange rate regimes that have been operated in some countries in history.

12 We would expect the relations on the foreign exchange market to be dominated by the exchange rate for domestic electronic currency as transactions are affected electronically. Already nowadays foreign exchange rates for paper currency transactions exhibit almost prohibitively wide spreads. 
Dual exchange rate regimes suffer from a number of problems making them unsustainable. In typical dual exchange rate regimes, central banks impose two different conversion rates for the unique local currency into foreign currency.

Figure 5. Illustration of uncovered interest parity with a dual local currency system

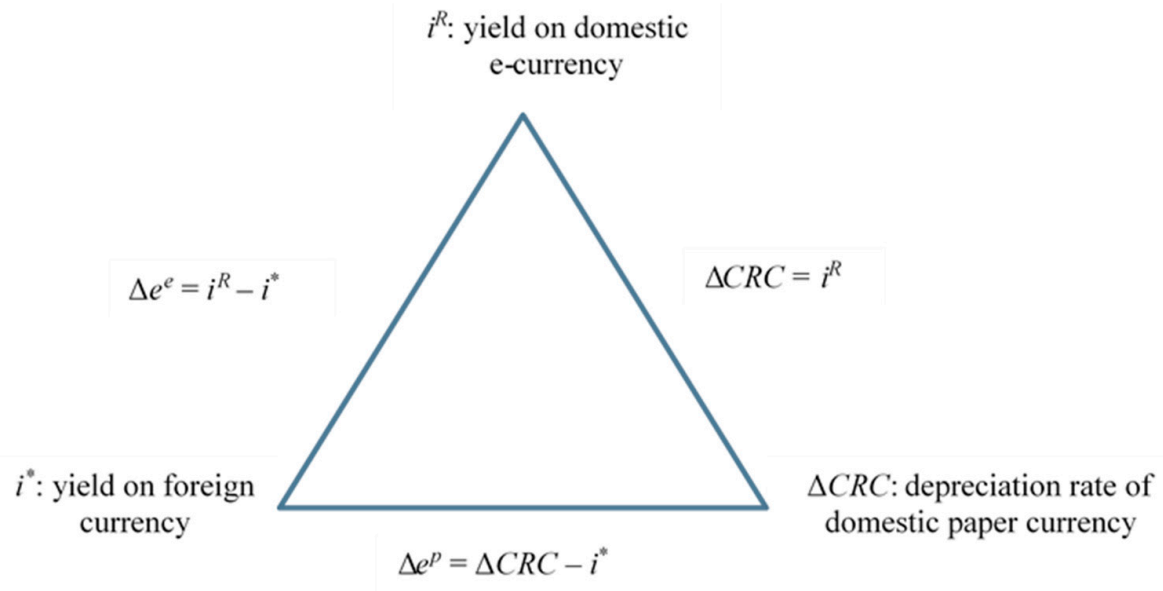

If the market for foreign currency is not controlled, there would be unlimited arbitrage opportunities from buying and selling foreign exchange at the two rates. To avoid such arbitrage, the central bank has to restrict or ration access to local or foreign currency at some of the rates. In history, black markets and rent seeking in response to the arbitrage opportunities have inevitably developed and have led to the downfall of dual exchange rate systems. Similar problems have characterized the historical experiences of early banks in issuing parallel currencies during eras of free banking. ${ }^{13}$ In contrast, the dual local currency regime that we discuss here is not associated with any unlimited arbitrage opportunities as long as the $C R C$ rate is set according to the principles discussed above. The central bank would issue two local currencies, set the interest rate on reserves and the conversion rate for reserves into cash consistent with this interest rate, and allow the market to set the respective exchange rates vis-à-vis foreign currencies. Arbitrage would be stabilizing for the system. It would ensure that the foreign exchange rates would be consistent with UIP. Currency controls or market rationing would not be required to make the system operational.

We conclude that the practical operation of a dual local currency system should not require major changes to current monetary policy frameworks. The interactions of the central bank with its counterparties under a dual local currency system are straightforward and would follow the same lines as monetary policy operations under

13 The Bank of Amsterdam operated an early version of a dual local currency system in the $17^{\text {th }}$ century by unbundling its deposits in unredeemable account balances (reserves) and coins that could be withdrawn (Quinn and Roberds 2014). The main difference to our scheme is that in a modern central bank both components, i.e. cash and reserves, are fiat money and thus unredeemable. 
contemporary systems. We next turn to how the yield on cash and the $C C R$ would transmit to the rest of the economy.

\section{B. Transmission Beyond Banks}

How would the introduction of the conversion rate transmit to the cost of using cash and electronic means of payments in the rest of the economy? The answer to this question is less clear, as it depends on behavioral, legal and other types of responses of the broader economy. There are no empirically relevant historical episodes that can inform these questions. We briefly discuss how banks and wholesale clients are likely to respond given current behavior, and use these considerations as a bridge to the central but unanswered questions about broader transmission addressed in Section IV.

Whether and how a commercial bank would pass on the conversion rate between reserves and cash to its customers would not need to be dictated by the central bank, but could remain a business decision by banks. Figure 6 provides an illustration of how the $C R C$ would be passed on from the central bank via the commercial banking system to retailers and consumers. As is evident from Figure 6, the behavior of cash handling companies, who typically carry out the transfer of cash between the central bank and commercial banks, and their price setting, would play a central role in the transmission of the $C R C$ to the economy.

Figure 6. Transmission of the cash reserve conversion rate

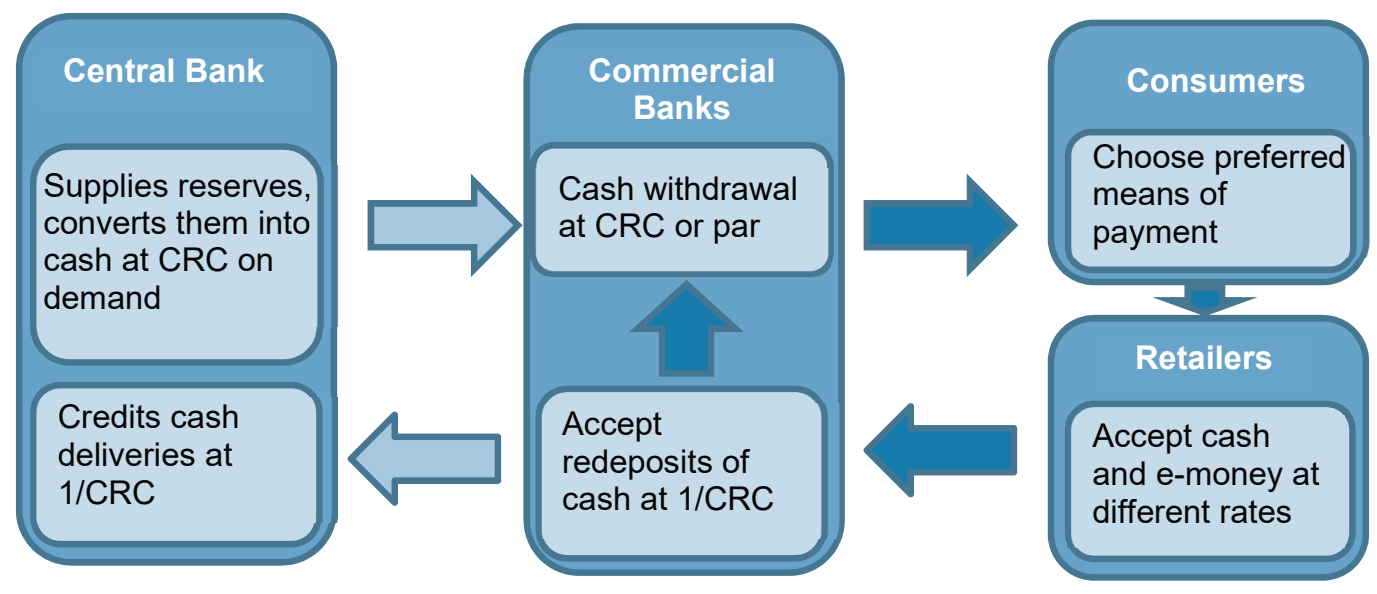

To make sure that this transmission is working properly, it is crucial that the $C R C$ is applied symmetrically by the central bank, i.e. that withdrawals are credited at above par, giving the cash handling companies an incentive to obtain cash at the central bank instead of trying to re-issue banknotes without channeling them through the central bank. If the $C R C$ would only apply to re-deposits of cash and not to withdrawals, there would be an incentive to short-circuit the cash cycle, and the transmission of the $C R C$ to the broader economy might be put at risk.

For relatively short and mild episodes of policy rates below zero (e.g. below a margin of a few percentage points and within a reasonably short period), it might not be 
passed on to banks' customers, as making the necessary changes would imply a oneoff cost for banks. Automatic teller machines could continue to work with a unit conversion factor, at least for retail-sized withdrawals and deposits, and merchants would likely continue to accept payments in whatever form the customer prefers. ${ }^{14}$ If banks have already paid the one-off cost of adapting systems to the $C R C$, however, passing on the $C R C$ could be immediate.

Moreover, in a slowdown that requires a longer episode of more substantially negative interest rates, the cost of conversion between cash and deposits would become steep enough for firms and/or banks to have to pass them on. Banks would be likely to implement the $C R C$ for their deposit holders at the latest at this point, and non-bank clients would become confronted with the dual local currency system and the conversion rate. Based on the current experience with banks passing on negative interest rates to institutional but not to retail clients, it is probable that the conversion rate would first be passed on to institutional, non-bank financial firms and possibly non-financial firms before households and small enterprises would be confronted with it.

Passing on the $C R C$ to bank customers should not create any problems for cash circulation or payments. Cash is usually withdrawn by the banks' retail customers from their deposit accounts and spent for purchases of goods and services. The bank would decide whether customers can withdraw cash at par or at the $C R C$ from their accounts. Shops and other firms receive such cash payments and bring it back to the bank, which then would likely credit these cash deposits at the conversion rate that itself faces at the central bank, i.e. firms' accounts with their bank would be credited at less than par. ${ }^{15}$

More uncertain is how the dual local currency system would transmit to pricing and price quotes - i.e. which currency, cash or reserves, would become the main unit of account. Confronted with a higher cost for depositing cash, firms would perhaps first - before charging cash prices that differ from e-money prices to their customers have an incentive to influence their customers towards paying with electronic means of payment instead of cash. ${ }^{16}$ If the value of cash deviates too much from that of

14 As Kimball (2015) also points out, this would correspond to the current system, in which different means of payment also bear different costs, but businesses prefer to take these costs onto their margins and generally do not differentiate prices according to different means of payment. Based on current limits for credit card fees that are absorbed by banks and businesses, one can speculate that this threshold resides somewhere around 3\% accumulated depreciation of cash relative to reserves.

15 The setting of the conversion rate would be a business decision of the bank. There would not be any requirement that this conversion rate has to be identical to the one the central bank is applying. Banks would be free to set a more or less favorable conversion rate for their customers. They could also choose to adjust it less frequently than the central bank, as it has been generally the case with deposit rates relative to the policy rates.

16 For small accumulated rates of depreciation of cash, this could initially take the form of bonuses or coupons for non-cash payments. 
reserves, however, firms will have to choose which currency to use for price quotes and let prices in the two currencies deviate.

The answers to the questions of which currency firms choose for price quotes, and which currency customers expect to see prices quoted in, are central for the functioning of a dual local currency system and its ability to remove the zero lower bound. We therefore address these questions in more detail below.

\section{ISSUES AND UNANSWERED QUESTIONS}

As the above discussion suggests, breaking the unit conversion between cash and reserves should be operationally feasible with minimal changes to frameworks and structures. To make a dual local currency regime ready for implementation in case of need, however, would also require changes to current legal and financial frameworks. The exact nature of such changes are more complex and will often be country and context-specific. Concrete proposals are beyond the scope of this paper. Instead, we discuss below what we consider to be the main issues and unanswered questions needing attention. We also discuss some unanswered questions about the transmission of deeply negative interest rates more generally to the broader economy.

\section{A. The Unit of Account and Legal Tender}

When considering the role of cash in the economy, an important issue is the concept of legal tender, including the currency denomination of legal contracts and the currency in which taxes can be paid. As we discuss below, introducing a dual local currency system could require legal and regulatory reforms to ensure that the interest rate on reserves transmits to the broader economy. How such reforms should be designed depends on the specific legal, institutional and cultural context of the individual country.

Money serves three functions. It is a means of exchange, a unit of account and a store of value. The first two functions distinguish money from other assets, which usually dominate money as a store of value because of their higher yield. Though extensive research has investigated the means-of-exchange function of money (e.g. Yeager 1968, Kiyotaki and Wright 1989), the unit-of-account function of money is much less well understood (see Buiter 2007). The unit of account is the currency used to value goods, services, assets, liabilities, income, expenses and so forth. Nominal contracts and invoices are written in the unit of account. Mental accounting also takes place in the unit of account, which affects behavior and decision making. It is hence the currency through which monetary policy is transmitted to the economy and, therefore, the currency in which potential frictions apply. ${ }^{17}$

For a dual local currency system to work, the electronic currency must become the unit of account. Citizens should measure their wealth and income in terms of units of

17 See Buiter (2007) for a formal model of this link. 
electronic currency, not cash. Prices should (ideally) be quoted in electronic currency; wage contracts and other important nominal contracts should predominantly be written in electronic currency to ensure this. Cash would remain a means of payment but cash users would be confronted with an inflation rate for cash prices that differs from the one for prices quoted in electronic currency. In a dual local currency system, the ZLB on cash will be removed through its depreciation relative to the unit of account, the electronic currency. This means that price stickiness must pertain to the electronic currency, as this is key to lowering the real interest rate when the nominal interest rate is moved into negative territory. As Buiter (2007) explains, if cash instead of electronic currency were to become the unit of account in a new dual local currency regime, economic agents would measure their incomes and assets in units of cash. The depreciation of cash in terms of reserves would be felt instead as an appreciation of reserves relative to cash. This appreciation could in turn nullify the negative interest on reserves, which consequently would not transmit to the rest of the economy.

How can we ensure that electronic currency becomes the relevant unit of account? In most current monetary systems, the use of the national currency as a unit of account is supported by declaring it legal tender. Throughout history, legal tender has served as an economy's main medium of exchange as well as the unit of account. ${ }^{18}$ Legal tender status implies that a given means of payment is recognized by the legal system to be valid for meeting financial obligations. ${ }^{19}$ Firms usually cannot refuse legal tender for settling debts, though the obligation to accept legal tender can be abrogated based on the freedom of contract. Private businesses are mostly allowed to develop their own policies regarding whether to accept banknotes or coins as payment for goods or services. ${ }^{20}$ However, legal tender usually is a liability towards the central bank, whereas other means of payments such as bank transfers or credit cards constitute a liability towards the financial institution that issues them. Holding and accepting other means of payment might be convenient, but is related to incurring some creditor risk.

In most countries, cash is the legal tender for historical reasons. Central bank reserves are sometimes included as well. In contrast, bank deposits - the main form of electronic money that non-bank citizens currently use and have access to - are not. They are accepted in payments only by convention, for convenience and through trust.

18 Buiter (2007) discusses some exceptions to this rule. Another example is the Chilean UF (Unidad de Fomento), which was introduced in 1967 and successfully used as an indexed unit of account (indexed to consumer price developments), while the pesos remained the means of exchange, means of storage as well as legal tender (Shiller 2002).

19 Throughout the history of economic thought the notion can be found that fiat money derives its value from being accepted by government in paying taxes, see the references given in Forstater (2005).

20 There is some variation across countries, with some countries stipulating that all merchants must accept cash, but such provisions are becoming increasingly obsolete with the rise of internet based shopping. For the US, there is no Federal statute mandating that a private business, a person, or an organization must accept currency or coins as payment for goods or services unless there is a state law which says otherwise (http://www.federalreserve.gov/faqs/currency 12772.htm). For Switzerland, the case seems less clear, see Aargauer Zeitung (10 July 2015) "Nespresso verweigert die Annahme vom Bargeld". 
Could the fact that non-banks currently do not have access to electronic legal tender prevent electronic currency from becoming the relevant unit of account in a dual currency system? Given the prevalence of cashless means of payment today, we do not regard this as a likely scenario. Kimball (2013), however, advocates for this reason that the legal tender status of cash be revoked in a dual currency system, leaving electronic currency as the sole legal tender. Yet, revoking legal tender status of cash would deprive non-bank citizens, who currently cannot hold reserves at the central bank, of access to legal tender. To address this, electronic currency could be made available to non-bank citizens as an electronic legal tender by giving them access to deposit and payments facilities at the central bank (Niepelt 2015). Some central banks are discussing the pros and cons of issuing digital central bank money as a complement to cash to non-banks, see e.g. Ingves (2017) or Mersch (2017).

Alternatively, banks could be required to offer special deposits that are backed by the bank's holdings of central bank reserves. ${ }^{21}$ These special deposits could then be granted legal tender status. Once an electronic legal tender circulates universally, further measures to ensure that this electronic currency becomes the unit of account would be unproblematic - and perhaps not even necessary.

A widely accessible electronic legal tender could have deep reaching implications for the structure of the financial system. Traditional demand for bank deposits could evaporate or change radially, eroding traditional bank funding models and the nature of payments systems. This could have implications for credit provision, and could raise questions about the role of the central bank in the allocation of credit that are beyond the scope of this paper. ${ }^{22}$ These issues are not specific to a dual local currency system and should be studied in their own right, as cash increasingly gives way to new electronic means of payment.

To make a dual local currency system work, it would be essential that new contracts are written in electronic currency. Buiter (2007) recommends that all contracts to which the state is a counterparty be written in electronic currency, that taxes be payable only in electronic currency, and further, that only contracts written in electronic currency be legally enforceable. While such an arrangement seems feasible for new contracts, a more challenging question is how to deal with existing, or legacy, contracts. Such transitional issues would need to be planned for to minimize disruptions when introducing a dual local currency system. The experiences of European countries joining the euro could provide initial insights and should be studied.

Specifically, keeping the legal tender status of cash in a dual local currency regime raises important issues related to how legacy nominal contracts should be honored when these do not specify a particular means of payment. If cash is depreciating but

21 Relatedly, in June 2018, Swiss citizens voted on whether to introduce a form of narrow banking that would go a long toward backing bank deposits fully with central bank legal tender. The proposal was rejected.

22 See Cochrane (2014). 
can be used to make good on a contractual agreement, this would create incentives for debtors to repay debts in depreciated units of cash, preventing electronic currency from becoming the relevant unit of account and leading to an unintended redistribution from creditors to debtors in the new regime. Contracts that govern recurrent payment obligations, such as mortgage or employment contracts, seem particularly problematic. Employers or mortgage holders (debtors) would have an incentive to pay the nominal wage or mortgage installments fixed in the contract in cash, as the cash amount would be worth less in terms of electronic currency. By contrast, employees and mortgage issuers (creditors) would have incentives to demand payment in electronic currency. If there is legal uncertainty with respect to which currency a contract refers to, a transition to a dual currency system can create legal problems and frictions. A shift to a new regime in which cash remains legal tender would therefore have to include amendments to legal frameworks governing contracts and payments on financial obligations.

\section{B. Behavioral Responses in the Transition}

Given the lack of precedents for systems that allow for deeply negative interest rates, and examples of monetary systems where the value of cash is decoupled from electronic money, the initial behavioral responses to the introduction of such an unfamiliar and relatively complex system are unknown. While economic theory can help guide us, it has clear limits. The behavioral response during the transition to a new system, when the public learns how it works, would be particularly unpredictable. In theory, it should be clear that a $C R C$ above unity means that cash depreciates over time. In practice, however, if public education efforts about the system are not successful, citizens, especially those that are less financially literate, might initially think that they get more cash for their deposits when deposits bear negative interest. If paper currency prices do not increase upon the introduction of the new system, it may add to the illusion that cash retains its purchasing power over time. This could initially lead to a run into cash, until it is broadly understood that cash can be redeposited only at a depreciating rate. While such problems would be temporary, it could create practical problems for central banks, e.g. they could temporarily run out of cash. Preparations for a smooth transition should hence include clear communication and large stocks of cash, as well as taking measures to improve the level of financial education of the population.

Another behavioral question for the transition is whether the introduction of a dual local currency system would send a crisis signal that could erode trust in the central bank, and perhaps lead people to switch to other forms of currency for their payments, such as foreign currency, gold or even cryptocurrency. We already see marginal shifts, for other reasons, in the types of means of payment used in many areas of the financial system. However, individuals seem to be unwilling to abandon local currency as a means of payments for most transactions. Based on data from five hyperinflations, Barro (1972) showed that even at rates of inflation above 100 percent annually, the domestic currency was still used, though the velocity increased substantially. While a shift toward alternative currencies could be accelerated by the 
introduction of a dual local currency system, it would not change the fact that only local currency is legal tender and needed for making good on various obligations. To avoid an outright large-scale destabilizing run on the domestic currency in connection with the introduction of a dual local currency system, the central bank would have to communicate the system and its merits well and carefully. Successful communication would recreate confidence that monetary policy has new and unlimited room to address a downturn. It should thereby reduce the already existing crisis sentiments that are likely to be prevalent in a situation where a central bank would want to introduce such a system. Transparency and the quality of communication of the system would be key for building trust. ${ }^{23}$

\section{Deeply Negative Rates and Monetary Policy Transmission}

To date, policy interest rates have only been moderately negative in some countries. The whole reason for introducing a dual local currency system is to be able to move interest rates into deeply negative territory in response to strong downturns when nominal interest rates are near zero. But does that work to stimulate the economy? In this section, we offer a tentative yes, but call for more research. Our considerations are necessarily speculative as there is no historical precedence to draw on. This uncertainty is a drawback in itself, but should be weighed against the rather certain adverse implications for the economic performance of not being able to provide monetary stimulus freely at the lower bound during steep downturns. If monetary policy is unable to counteract economic downturns forcefully because of the zero lower bound constraint, long periods of below-average interest rates can have adverse effects on growth and employment and in turn on the health of financial institutions (International Monetary Fund, 2016). Being able to cut interest rates into_deeply negative territory could help shorten a downturn and the resulting low-growth period, getting the economy faster back on track and thus back into positive interest rate territory.

Against that background, we first reflect on whether experiences with how moderately negative interest rates have transmitted to financial conditions more broadly in the economy can inform how this would work in more deeply negative interest rate environments. In turn, we discuss how economic agents might respond in terms of savings and investment behavior. Financial stability aspects of deeply negative interest rates are considered in the next section.

Interest rates on money and bond markets have fallen in line with monetary policy rates like in normal times when interest rates became negative. There is no convincing reason why such rates would not keep declining with policy rates if these were to be

23 A related observation is that there is no reason that a large-scale capital flight would have different implications in a dual local currency system. We would expect to see a depreciation of the domestic currency in a floating rate system or an expansion of central bank reserves through foreign exchange interventions in a fixed exchange rate system (both of which should help bring back inflation faster). The central bank would have to be prepared in terms of foreign exchange reserve adequacy or macroprudential measures to prevent balance sheet vulnerabilities to such episodes. 
lowered further. Whether bank lending rates would follow suit is less clear. Some studies question the ability of too negative interest rates to transmit to bank lending. For instance, Brunnermeier and Koby (2017) argue that due to the interplay between negative interest rates, regulation and liabilities fixed in nominal terms (such as pension liabilities), interest rate cuts cease to stimulate bank lending if rates become too low. They capture such effects in the so-called reversal rate. Once recapitalization gains are offset by tighter interest margins, low interest rates reverse their effect. Following similar reasoning, Eggertson et al. (2017) build a model to show that a lower bound for deposit rates limits the extent to which a central bank can stimulate the economy by lowering its policy rate. These studies, however, take the existence of a zero yield on cash and therefore a lower bound on deposit rates as given. ${ }^{24}$ With a negative yield on cash, and if deposit rates breach the sticky line of zero, we see no technical impediments for banks to transmit interest rate changes to deposits and lending at a deeply negative interest rate level.

If interest rates can be turned deeply negative, will economic agents respond by increasing investments and reducing savings? Or might they respond counterproductively by saving even more, to compensate for lost interest income? The debate over this question rages each time monetary policy is used aggressively to counter an economic downturn when savings rates increase. It is notoriously difficult to inform this question by empirical evidence due to difficulties in measuring the monetary policy stance implied by the nominal interest rate level, as well as establishing causality from interest rates to savings in such events. Adding to this, there are no data to investigate how economic agents respond to deeply negative nominal rates. But a few observations can be made. First, what should matter for savings and investment behavior is the real interest rate, not the nominal rate. And real interest rates have been negative on many occasions in many countries, as inflation has been substantially above policy rates, notably in the 1970s and during the post-global financial crises years. If changes in neutral real interest rates are appropriately accounted for, such episodes do seem to be associated with improvements in macroeconomic conditions, as theory and the Euler equation would suggest (Krogstrup 2017). There is little evidence that negative real rates would generate a discreet behavioral shift toward savings (see also Ball et al. 2016), although more research on savings and investment behaviour during negative real interest rate episodes would be desirable. Second, we cannot exclude that deeply nominal interest rates might have such effects. Economic agent may partly allow nominal considerations to guide their decisions, at least in the short term, due to money illusion. More research is needed to address this question, for example by using similar experimental research methods used to confirm money illusion (e.g. Fehr and Tyran 2001). In any case, clear and targeted central bank communication

24 While deposit rates have not moved below zero to date, rates on money and bond markets have, so that nondeposit funding has become cheaper for banks in negative interest rate countries. Evidence presented in Ball et al. (2016) suggests that the transmission to bank lending rates in Switzerland following the interest rate cut into negative territory was indeed weaker than usual. This pattern, however, was not seen in other negative interest rate countries where bank lending rates responded normally. 
and financial education could go a long way in reducing the impact of money illusion, both preventively and during severe economic downturns when interest rates would have to fall into negative territory. Moreover, a shift to a dual local currency regime could in itself reduce money illusion by confronting economic agents with more than one unit of account.

In conclusion, we see no reasons to anticipate that monetary policy transmission to savings and investment behavior would be hampered with deeply negative interest rates. The main uncertainty is the unknown effects of deeply nominal rates due to money illusion. Associated risks can be minimized with appropriate communication and education efforts, and are likely to be transitional.

\section{Deeply Negative Rates and Financial Stability}

To date, cash has circulated at par and retail deposit rates at most banks have not been moved into negative territory. Would a deeper dive into negative interest rate territory, including negative deposit rates and a separate cash currency, have negative implications for financial stability? We address this question below, keeping in mind that these considerations are necessarily speculative, but should be viewed against the background of much more certain adverse implications for financial stability of not being able to provide monetary stimulus at the lower bound. We consider five different possible implications for financial stability.

First, a dual local currency system per se could strengthen financial stability, and the authorities' tools to steer it, since it would remove an incentive for bank customers to withdraw deposits on a large scale. This presumes that the $C R C$ is transmitted to wholesale and retail cash prices such that agents are indifferent between using cash with a zero interest rate at depreciating prices or electronic money subject to a negative rate on deposit accounts. The authorities could use the $C R C$ rate actively to steer the incentive to run into cash._Financial stability implications of a dual local currency system could arise, however, if an electronic legal tender was made accessible for all citizens. Policy and regulation could be designed so as to ensure that these changes would be in a direction that would reduce the risk of bank runs. ${ }^{25}$ When deposits can be withdrawn quickly from banks and safely stored electronically with the central bank, generalized bank runs could become more severe, rendering the aggregate funding base of retail banks more volatile and susceptible to bad news. Such financial stability concerns are not caused by negative rates per se but depend on the general access to, and the design of, central bank issued electronic currency. The problem is mitigated if central banks stand ready as lenders of last resort during such events. Moreover, bank funding models would have to change if faced with competition from a universal legal tender.

25 Similar concerns have been voiced in the context of the Federal Reserve's reverse repurchase (RRP) program, which gives financial institutions access to the Federal Reserve's balance sheet as a counterparty in repo operations, see for example Anderson and Kandrac (2016). Observing how the RRP program works during a possible future financial instability event could help inform on this issue. 
Second, if the issues regarding the unit of account discussed in Section IV above are properly addressed in the design of and transition to a dual local currency system, financial stability implications related to changes in the value of financial contracts could be minimized.

Third, it is occasionally argued that negative interest rates have adverse effects on bank profitability, with ensuing negative consequences for financial stability. ${ }^{26}$ Banks have in general not been willing to impose negative interest rates on retail deposits (Jackson 2015, Jobst and Lin 2016, Bech and Malkhozov 2016). Consequently, bank funding costs have not decreased as much as policy rates, narrowing the interest margin. In general, there is no evidence that bank profitability has been negatively affected by negative interest rates per se (Ball et al. 2016). Banks' responses to negative interest rates have differed across countries. To maintain profitability, banks have increased their fee based revenue ${ }^{27}$ or lowered lending rates less than they would have done in response to an interest rate cut in positive territory. ${ }^{28}$ It is questionable, however, whether recent experiences can inform how bank profitability would be affected in a situation with deeply negative rates in a dual local currency system. Deposit rates would be unlikely to remain sticky around zero and interest margins could hence be preserved. Moreover, the new business of converting electronic currency into cash and vice versa for customers at a crawling conversion rate could become a new source of income for banks, allowing them to earn a spread on this conversion.

Fourth, financial stability could be affected when financial institutions' business models incorporate nominal rigidities due to contractual definitions for nominal liabilities. Money illusion has been found even for institutional investors, and behavioral changes cannot be excluded when rates move substantially below zero. Pension funds could for example shy away from lowering nominal commitments to future pension benefits enough, making themselves financially fragile, or they could intensify search-for-yield behavior to avoid having to report negative returns. ${ }^{29}$ This potential risk, however, is not specific to negative interest rates, but relevant for long periods of below-average interest rates as well. As such, it is even more of a risk in

26 Nucera et al. (2017) find that euro-area banks, especially those that are predominantly deposit funded, are perceived to be more risky after a reduction in interest rates into negative territory than after a conventional interest rate cut.

27 Humphrey (2016) presents some calculations on the level of the fees the banks would need to impose to recover their negative-interest related cost.

28 An example is the interest rate floor clauses that Spanish banks applied to avoid that interest on floating-rate mortgages would fall too much (https://www.bde.es/f/webbde/GAP/Secciones/SalaPrensa/NotasInformativas/13/Arc/fic/presbe2013_31e.pdf).

29

Heider et al. (2017) find evidence that deposit funded banks start to lend to riskier borrowers when interest rates become negative. 
the present system where countercyclical monetary policy is hampered and cannot contribute to reducing the length of a downturn. ${ }^{30}$

Finally, McAndrews (2015) discusses various other issues that might arise in the context of negative interest rates, related to the implied change in direction of interest payment flows and the current definition of default. In particular, negative coupons on bonds seem impractical, as the issuer of the bond would have to collect interest payment from the bond holder. Typically, issuers are not aware of who is holding their bonds, whereas bond holders have an incentive to collect their interest from the issuer. With a negative coupon this incentive structure would be reversed. Moreover, a default on the coupon payment would be unrelated to the creditworthiness of the issuer and the quality of the bond. During the recent experience with negative interest rates, negative yields on bonds have been achieved by issuing the bond at a price above par. While this is unproblematic with slightly negative rates, it could raise issues when interest rates become significantly negative. ${ }^{31}$ With negative rates, present values become unbounded. Another issue is taxes, which often apply to coupon payments but not to capital gains. ${ }^{32}$

All in all, whether there would be adverse financial stability implications of a system allowing for deeply negative interest rates is unclear, while there are clear negative consequences of long periods of below-average interest rates and growth. Given this uncertainty, implementing a dual local currency system would have to be done cautiously with the appropriate legal and regulatory framework in place. Close monitoring and readiness to adapt to changing circumstances would be essential.

\section{E. Implications for Seigniorage Revenues}

Finally, introducing a dual local currency system could have implications for the central bank's seigniorage revenues. The implications crucially depend on whether commercial banks or the central bank itself provide non-banks with electronic currency. Although the central bank would not incur losses as long as interest rates are negative, the situation could change once interest rates rise. If the $C R C$ were to

30 Lucas et al. (2017) investigate bank business models at zero interest rates. They find that banks respond to changes in the yield curve. In particular, lower long-term interest rates lead to increased size, leverage, complexity and a less stable funding base for banks. This suggests that monetary policy measures targeted at longer term rates may also have financial stability implications.

31 A coupon payment can be regarded as a monitoring device, in particular for long-maturity bonds, as a regular coupon payment demonstrates the borrower's continuing capacity to pay to the bond holder.

32 In a legal and accounting sense, it is unclear how to treat negative interest rates. In its 1979 ruling, the Swiss Federal Court of Justice classified a negative interest on foreign capital inflows as a fee, meaning that it is not tax-deductible. For a more recent discussion see the International Financial Standards (IFRS) Interpretation Committee http://www.ifrs.org/-/media/feature/meetings/2015/january/ifrs-ic/ias-39-financial-instruments/ap4negative-interest-rates.pdf. 
remain in place with positive policy rates, as discussed in Section III, the central bank would be required to remunerate reserve accounts at the policy rate. ${ }^{33}$

Seigniorage revenue arises from the difference between the yields on the central bank's assets and its liabilities. Currently, the zero interest rate on cash - and in some countries also reserves - is the primary source of the central bank's seigniorage revenue. Increases in the use of electronic means of payment at the expense of cash can thus affect the long-term profitability of the central bank. A transition to a dual local currency system with the electronic currency as the relevant unit of account could presumably lead to an acceleration of the use of electronic payments at the expense of cash use. A decrease of cash in circulation and an associated reduction of the central bank's balance sheet could both decrease seigniorage. While generating profits is not the target of a central bank, sufficient seigniorage revenues to cover operating costs are often seen as important in ensuring central bank independence and therefore credibility. More research is needed to assess how much seigniorage could decrease and whether it could be severe enough to affect the central bank's ability to pursue its price stability target.

The potentially significant reduction of the central bank's balance sheet has also led to discussions about the size of the monetary base that is necessary to effectively implement monetary policy. While Friedman (1999) expresses concerns that an evaporating demand for base money would make it more difficult for the central bank to control financing conditions in the economy, Woodford (2000) argues that the central bank would continue to be able to control short-term interest rates even if the demand for base money were completely eliminated. Monetary policy effectiveness thus would be independent of the size of the central bank's balance sheet.

The implication of a dual local currency system for the central bank's balance sheet crucially depend on whether commercial banks or the central bank itself provide nonbanks with electronic currency. If the central bank were to supply digital currency to non-banks, motivated, for instance, by a desire to provide a generally accessible legal tender, an increased demand for an electronic legal tender would lengthen the central bank's balance sheet, forcing it to acquire more (interest-bearing) assets to counterbalance its increased liabilities. This could raise governance issues, as more credit would be intermediated through the central bank instead of the private sector. At the same time, a larger part of the central bank's liabilities would be remunerated at the policy rate. While the yield spread becomes smaller when interest-bearing reserves replace cash, seigniorage revenues might increase or decrease, depending on how much the balance sheet expands.

33 Some central banks, e.g. the ECB, have always paid interest on reserves whereas other central banks, e.g. the Fed, recently shifting to paying interest on reserves. 
As important as these considerations are, central bank seigniorage revenue is likely to change in future irrespectively, driven by financial innovation and the ensuing increased use of electronic means of payment at the expense of the demand for cash.

\section{Conclusions}

The zero lower bound on nominal interest rates is due to the availability of cash that yields a zero nominal return. De-bundling cash from electronic currency and making cash depreciate relative to electronic currency, as proposed by Buiter (2007) and Kimball (2015), could solve this problem. With such a system in place, a central bank would be able to use conventional monetary policy tools without the constraints of the lower bound to stabilize the economy. In a world of low neutral real interest rates, it would help reduce the length of business cycle downturns and hence the duration of low interest rate episodes. It would do so without dispensing of cash. Studies that question the transmission of negative rates to bank lending assume that banks cannot lower their deposit rates, which would not be a constraint in a dual local currency system.

Our discussion suggests that the system is technically feasible and would not require drastic changes to current mandates or operating frameworks of central banks. Moreover, in contrast to some other proposals, the system would be fully reversible. After a sufficient normalization of economic conditions, it could be exited if so desired. Any possible risks to the transmission of monetary policy and to financial stability should be addressed with clear and targeted central bank communication and financial education. Communication would be central for a successful introduction of such a regime. Moreover, further work would be needed to identify, prepare and implement the necessary legal reforms for ensuring its effective operation.

In our view, the dual local currency system should be considered alongside alternative proposals for keeping monetary policy effective at low interest rates, such as a higher inflation target proposed by Blanchard et al. (2010), or Quantitative Easing (QE). All current proposals, including the status quo, have pros and cons. In comparison to alternatives, the dual local currency system has the advantage of completely freeing monetary policy from a lower bound, allowing for effectively redressing and hence shortening the duration of recessions. Raising the inflation target and QE do not remove the lower bound but would shift it downward by some percentage points (Ball et al. 2016). Another advantage is that it can be implemented as a crisis measure, ideally with some preparation beforehand. In contrast, to reap all benefits of raising the inflation target, it should ideally be raised in good times, allowing time for expectations to adjust and credibility to be built around a higher level of inflation. ${ }^{34}$ Other advantages include the dual local currency system's reversibility, its

34 If the inflation target is raised as a crisis measure, it works through expectations of future inflation and is akin to forward guidance. This requires strong credibility and there are limits to the additional firepower that can be achieved as evidenced by the Japanese experience, see also Ball et al. (2016). 
preservation of a role for cash, and the fact that its introduction would reconfirm the central bank's commitment to the inflation target rather than raise doubts about it.

But the dual local currency system clearly also has disadvantages. Most importantly, it would be an enormous communicational challenge. It would also require more farreaching changes to the financial and legal system than simply raising the inflation target or pursuing QE. The key challenge, in our view, remains to ensure that electronic currency becomes the relevant unit of account despite the continued presence of cash, which is a prerequisite to being able to overcome the ZLB on interest rates. Without historical precedent, we can only speculate about the legal and regulatory changes that are necessary to make people regard prices set in electronic currency, and not in cash, as relevant to their economic decisions.

Technological innovation in electronic payments systems is proceeding at a rapid pace, without central banks actively promoting this (Casey et al., forthcoming). Such changes may force a reconsideration of issues around cash and legal tender in the future, irrespective of zero lower bound considerations. In this context, new developments should also be evaluated in light of their ability to accommodate negative policy rates, or even a dual local currency system. Pros and cons of a dual local currency system as well as alternative solutions should be carefully compared in the context of countries' individual institutional, legal, cultural and economic situation when considering the future of monetary policy frameworks. 


\section{REFERENCES}

Anderson, Alyssa G., and John Kandrac (2016), "Monetary Policy Implementation and Private Repo Displacement: Evidence from the Overnight Reverse Repurchase Facility," Finance and Economics Discussion Series 2016096. Board of Governors of the Federal Reserve System (U.S.).

Agarwal, Ruchir, and Miles Kimball (2015), "Breaking Through the Zero Lower Bound," IMF Working Paper WP/15/224.

Ball, Lawrence, Patrick Honohan, Joseph Gagnon and Signe Krogstrup (2016), "What Else Can Central Banks Do?" Geneva Report on the World Economy No. 18, ICMB and CEPR.

Barro, Robert J. (1972), "Inflation ary Finance and the Welfare Cost of Inflation," Journal of Political Economy 80 (5), 987-1001.

Bech, Morton L. and Aytek Malkhozov (2016), "How Have Central Banks Implemented Negative Policy Rates," BIS Quarterly Review, March 2016, 31-44.

Blanchard, Olivier, Giovanni Dell'Ariccia, and Paolo Mauro (2010), "Rethinking Macroeconomic Policy”, IMF Staff Position Note 10/03.

Brunnermeier, Markus K., and Yann Koby (2017), "The 'Reversal Interest Rate': An Effective Lower Bound on Monetary Policy," mimeo, Princeton University, http://scholar.princeton.edu/sites/default/files/markus/files/17e_reversa lrate.pdf.

Buiter, Willem. H. and Nikolaos Panigirtzoglou (2003), "Overcoming the Zero Bound on Nominal Interest Rates with Negative Interest on Currency: Gesell's Solution,” The Economic Journal 113: 723-746.

Buiter, Willem H. (2007), "Is Numérairology the Future of Monetary Economics? Unbundling Numéraire and Medium of Exchange through a Virtual Currency with a Shadow Exchange Rate," Open Economies Review $18,127156$.

Buiter, Willem H. (2009), "Negative Nominal Interest Rates: Three Ways to Overcome the Zero Lower Bound," North American Journal of Economics and Finance 20(3), 213-238.

Casey, Michael, Jonah Crane, Gary Gensler, Simon Johnson and Neha Narula, forthcoming, "The Potential Impact of Blockchain Technology on Finance: Small, Significant, or Completely Transformative?", Geneva Report on the World Economy No. 20(1), ICMB and CEPR 
Cheney, Julia S. (2006), "The Role of Electronic Payments in Disaster Recovery: Providing More than Convenience", Conference Summary, Federal Reserve Bank of Philadelphia.

John H. Cochrane (2014), “Toward a Run-free Financial System,” in: Martin Neil Baily and John B. Taylor (eds), Across the Great Divide: New Perspectives on the Financial Crisis, Chapter 10, Hoover Institution, Stanford University.

Eggertson, Gauti B., Ragnar E. Juelsrud and Ella Getz Wold (2017): “Are Negative Nominal Interest Rates Expansionary?” NBER Working Paper 24039.

Esselink, Henk, and Lola Hernández (2017), "The Use of Cash by Households in the Euro Area," European Central Bank, Occasional Paper, 201.

Forstater, Mathew (2005), “Tax-Driven Money,” in M. Setterfield, ed., Complexity, Endogenous Money, and Exogenous Interest Rates, Cheltenham, U.K.: Edward Elgar, 202-220.

Gagnon, Joseph E., and Brian Sack (2014), "Monetary Policy with Abundant Liquidity: A New Operating Framework for the Federal Reserve," Peterson Institute for International Economics, Policy Brief PB14-4.

Gesell, Silvio (1916), „Die natürliche Wirtschaftsordnung durch Freiland und Freigeld," Selbstverlag, Les Hauts Geneveys 1916; 9. Auflage herausgegeben von Karl Walker: Rudolf Zitzmann Verlag, Lauf 1949

Goodfriend, Marvin (2000), "Overcoming the Zero Lower Bound on Interest Rate Policy”. Journal of Money, Credit, and Banking,

Goodfriend, Marvin (2016), "The case for Unencumbering Interest Rate Policy at the Zero Bound". Paper presented at the Economic Symposium, Jackson Hole, August.

Heider, Florian, Farzad Saidi and Glenn Schepens (2017), “Life Below Zero: Bank Lending Under Negative Policy Rates” SSRN-id2788204.

Humphrey, David B. (2016), "Negative Interest Rates and the Demand for Cash," Journal of Payments Strategy and Systems 9, 280-289

Ingves, Stefan (2017), "Do we need an e-krona?" Speech given at the Swedish House of Finance, Stockholm, 8 December 2017, https://www.riksbank.se/en$\mathrm{gb} /$ press-and-published /speeches-and-presentations/2017/ingves-do-we-need-an-e-krona/.

International Monetary Fund (2014), "Perspectives on Global Real Interest Rates." Chapter 3 in World Economic Outlook, April 2014. 
International Monetary Fund (2016), "Global Financial Stability Report: Fostering Stability in a Low-Growth, Low-Rate Era”, Washington, October 2016.

Jackson, Harriet (2015), "The International Experience with Negative Policy Rates," Bank of Canada Staff Discussion Paper 2015-13.

Jacobsen, Johan Gustav Kaas and Søren Truels Nielsen (2011). "Payment Habits in Denmark". In Danmarks Nationalbank Quarterly Monetary Review, $3^{\text {rd }}$ Quarter 2011, Part 1, 123-134.

Jensen, Carina and Morten Spange (2015), "Interest Rate Pass-Through and the Demand for Cash at Negative Interest Rates". In Danmarks Nationalbank Quarterly Monetary Review $2^{\text {nd }}$ Quarter 2015.

Jobst, Andreas and Huidan Lin (2016), "Negative Interest Rate Policy (NIRP): Implications for Monetary Transmission and Bank Profitability in the Euro Area," IMF Working Paper WP/16/172.

Kimball, Miles S. (2015), "Negative Interest Rate Policy as Conventional Monetary Policy," National Institute Economic Review 234, November, R5R14.

Kiyotaki, Nobohiro and Randall Wright (1989), "On Money as a Medium of Exchange,” Journal of Political Economy 97, 927-954.

Krogstrup, Signe (2017), "Monetary Policy Accommodation at the Lower Bound", Business Economics, Palgrave Macmillan; National Association for Business Economics, vol. 52(1), pages 7-14, January.

Lucas, Andre, Julia Schaumburg and Bernd Schwaab (2017), "Bank business models at zero interest rates" ECB Working Paper no. 2084.

Mankiw, Gregory (2009), "It May Be Time for the Fed to Go Negative," New York Times (April 18).

McAndrews, James (2015), "Negative Nominal Central Bank Policy Rates: Where Is the Lower Bound?" Remarks at the University of Wisconsin, May 8, 2015, http://www.ny.frb.org /newsevents/speeches/2015/mca150508.html.

Mersch, Yves (2017), “Digital Base Money: an assessment from the ECB's perspective", speech given at the farewell ceremony for Pentti Hakkarainen, Deputy Governor of Suomen Pankki, Helsinki, 16 January 2017, https://www.ecb.europa.eu/press/key/date/2017/html /sp170116.en.html. 
Niepelt, Dirk (2015), "Reserves for everyone - towards a new monetary regime?", Vox-EU column, January 21, 2015.

Nucera, Federico, Andre Lucas, Julia Schaumburg and Bernd Schwaab (2017), "Do negative interest rates make banks less safe?" ECB Working Paper no. 2098.

Quinn, Stephen and William Roberds (2014): "How Amsterdam Got Fiat Money," Journal of Monetary Economics 66, 1-12.

Rogoff, Kenneth, (2014) “Costs and Benefits to Phasing Out Paper Currency," NBER Working Paper No. 20126.

Seltmann, Thomas (2010): “Umlaufsicherung von Banknoten”, Humane Wirtschaft 02/2010, 10-16.

Shiller, Robert (2002), "Indexed Units of Account: Theory and Assessment of Historical Experience", in: Fernando Lefort and Klaus Schmidt-Hebbel (eds), Indexation, Inflation and Monetary Policy, Santiago, Central Bank of Chile, 105-134.

Skingsley, Cecilia (2016), "Should the Riksbank issue e-krona?", Speech at FinTech Stockholm 2016, 16 November 2016, http:/www.riksbank.se/Documents/Tal/Skingsley/2016 tal skingsley 161116 eng.pdf.

Svensson, Lars E. O. (2003), "Escaping from a Liquidity Trap and Deflation: The Foolproof Way and Others.” Journal of Economic Perspectives, 7(4), $145-166$.

Swiss National Bank (2017), "Survey on Payment Methods),

https://www.snb.ch/en/mmr

/reference/paytrans_survey_report_2017/source/paytrans_survey_repor t_2017.en.pdf.

Williams, John C., 2017. "Preparing for the Next Storm: Reassessing Frameworks and Strategies in a Low R-star World," FRBSF Economic Letter, Federal Reserve Bank of San Francisco.

Yeager, Leland B. (1968), "Essential Properties of the Medium of Exchange," Kyklos $21,45-49$. 